\title{
EMERGING TRENDS IN SUPPLY CHAIN MANAGEMENT
}

\author{
Gyanendra Singh $^{1}$, Rajeev Arora ${ }^{2}$, Vivek Mishra ${ }^{3}$ \\ ${ }^{1}$ Department of Mechanical Engg, Invertis University Bareilly \\ ${ }^{2}$ Department of Mechanical Engg, Invertis University Bareilly \\ ${ }^{3}$ Student Department of Mechanical Engg, Invertis University Bareilly
}

\begin{abstract}
Supply chain management, in recent times, has emerged as the basis in many industries (small or large) for creating the integrated relationship between suppliers and customers. Due to continuous growth in last year in supply chain management the environment has become competitive. So in order to respond to competitive pressures companies need to know and understand the new trends in SCM. This paper focuses the emerging trends of SCM in current scenario, and it provides broader awareness of SCM concepts. It addresses this need, by critically reviewing the current status of SCM in Indian context and its point of difference with other countries like China. Managing the Supply chain by making use of I.T. services has paved a new way of confiscating the uncertainty and enhancing the customer service and thus creating a competitive edge.
\end{abstract}

Keywords: Supply Chain Management, Vendor Management Inventory, Collaborative Planning Forecasting and Replenishment, Cross docking, Radio Frequency Identification, Advanced planning and scheduling. $* * *$

\section{INTRODUCTION}

Supply Chain Management is the management of a network of interconnected businesses involved in the ultimate provision of product and service packages required by end customers (Harland, 1996) [1]. Supply Chain Management spans all movement and storage of raw materials, Work-inprocess inventory, and finished goods from point of origin to point of consumption In the words of The Supply Chain Council," SCM is defined as managing supply and demand, sourcing raw materials and parts ,manufacturing and assembly, warehousing, order entry and order management, distribution across all channels, and delivery to the customers". [1]

Ellram and Cooper have defined SCM as "an integrating philosophy to manage the total flow of a distributed channel from supplier to ultimate customer". The concept of Supply Chain is not a new concept worldwide, it has increased steadily since 1980 , when companies began to make their collaborative relationships with suppliers, manufacturers and vendors. In Indian Context, it is a still at nascent stage.

SCM is constantly evolving and there are always new trends. With companies investing ever greater resources in their supply chain there is a distinct trend to have the best and brightest employees managing those supply chains. Supply chain professionals are always evaluating possible inefficiencies and shortcomings of their supply networks to improve their ability to deliver to the customer. This is especially true in today's fast paced, highly competitive environment where supply chain performance can provide manufacturers with a necessary edge .In order to face a number of challenges and to be at the forefront, companies are required to update their skills and introduce new innovations in their Supply Chain

\section{OBJECTIVES OF THE STUDY}

A. To understand the concept of SCM

B. To know the trends in SCM

C. To know the present status of Supply Chain in India

D. To compare the India's Supply Chain with that of China

\section{SCM NETWORK}

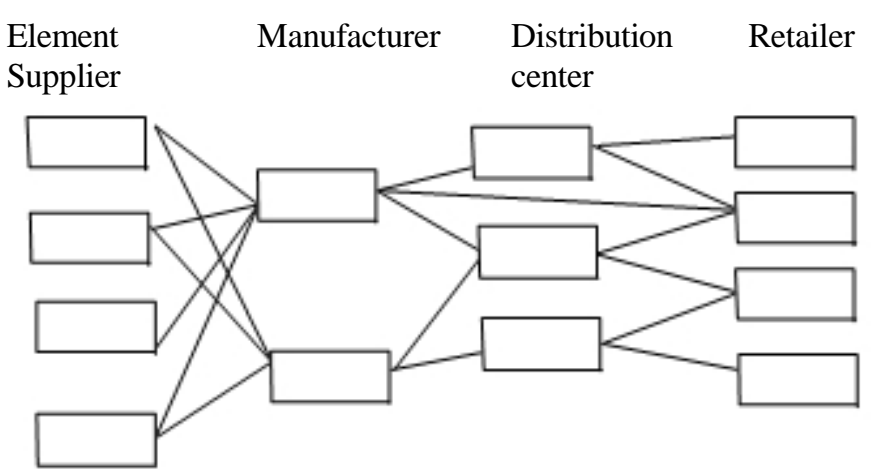

\section{INNOVATIONS IN SCM}

Companies need to be willing to make necessary and difficult changes. Success requires reducing cost base through control on expenses and redesigned work processes. Logistics cost which is incurred as a percentage of GDP is 11.6\%.[3] In order to improve their productivity they need to work on new products and trends. Some o the new innovations are as-

\subsection{Vendor Management Inventory (VMI)}

VMI is a distribution channel operating system whereby the inventory at the distributor/retailer is monitored and managed by the manufacturer vendor. It is a family of 
business model in which buyer of a product provides certain information to the supplier of that product and the supplier takes full responsibility for maintaining an agreed inventory of the material, usually at the buyer's consumption location. It includes several activities including determining appropriate order quantities, managing proper product mixes.VMI is also QRIS (Quick response inventory system) The vendor's computer acquires data electronically, no manual data entry is required at the recipient's end which help in reducing the lead time and in eliminating the vendors recording errors.

Ex.Home Depot [4]

\subsection{Collaborative Planning Forecasting and}

\section{Replenishment (CPFR)}

CPFR can be defined as a collaboration where two or more parties in the supply chain jointly plan a number of promotional activities and work on synchronized forecasts, on the basis of which production and replenishment processes are determined. The term CPFR was first introduced in 1995, in connection with a pilot project between Wal-Mart. Warner-Lambert, Benchmarking partners, SAP and Manugistics The objective of CPFR is to better align supply and demand through trading partner data interchange exception based management and structured collaboration in order to eliminate issues and constraints in fulfilling consumer expectations.

CPFR is a business practice that reduces inventory costs while improving product availability across the supply chain. The CPFR process begins with an agreement between the trading partners to share information with each other and to collaborate on planning with the ultimate goal of delivering products based on true market demand.

Ex. Wal-Mart.[5]

\subsection{Cross Docking}

Cross docking is a practice in Logistics of unloading materials from an incoming semi-trailer, truck or rail, car and loading this material directly into outbound trucks, trailers, or rail cars, With little or no storage between them. It is a function of warehouses or distribution centers, which was introduced by Wal Mart.

Cross docking is a system in which the vendor's ship merchandise to a distribution centres in pre packed quantities required by each store. The merchandise is delivered to one side of the distribution centre; the floor ready merchandise is then transferred to the other side of distribution centre for delivery to a store.

Cross docking is a process by which products are aptly room the inbound dock to the outbound dock, avoiding the need to store and prepare order replenishment.

It either picked or moved directly from the inbound dock to the outbound dock, avoiding the need to store and prepare order replenishment.
It not only reduces material handling but also reduces the need to store the products in the warehouse.

\subsection{Radio Frequency Identification (RFID)}

It is a technology that uses communication via electromagnetic waves to exchange data between a terminal and an object such as product, animal, or person for the purpose of identification and tracking. it is a device that contains a chip and an antenna, which can be physically inserted or stuck to a product.[6] The basic information about the product can be stored in this chip. The tagging of this chip enables companies to identify and track their goods at various levels in a distribution chain.

The reason this technology is being increasingly used is due to its extraordinary ability to track almost anything and know where it is at any step of the distribution process.

The end result, companies become more efficient increase sales and reduce costs.

Ex. Wal-Mart, SamSys Technologies of Richmond Hills.[7]

\subsection{Advanced Planning and Scheduling}

It is also referred to as APS and Advanced Manufacturing. It refers to a manufacturing management process by which raw materials and production capacity are optimally allocated to meet the demand. APS is especially well suited to environments where simpler planning methods cannot adequately address complex trade-offs between competing priorities. Traditional planning system utilize a stepwise procedure to allocate material and production capacity. This approach is simple but cumbersome, and does not readily adapt to changes in demand, resource capacity or material availability.

APS has commonly been applied where one or more of the following conditions are present-

1) Make to order manufacturing

2) Capital intensive production processes, where plant capacity is constrained

3) Products that require a large number of components or manufacturing tasks

Advanced planning and scheduling software enables manufacturing scheduling and advanced scheduling optimization within these environments.

\subsection{Electronic Data Interchange- (EDI)}

It is the structured transmission of data between organizations by electronic means. It is used to transfer electronic documents or business data from one computer system to another computer system. It also be called as electronic document interchange. It is the exchange of business information through standard interfaces by using computers. It interoperated as transmission of business data between organizations in a computerized format that does not require the rekeying information.

Ex. Reliance Retail 


\section{Benefits of EDI}

It saves time

Manual errors can be avoided

It reduces costs involved in paper handling filing

\section{STATUS OF INDIA'S SUPPLY CHAIN}

According to Kamal Vohra, Lead Analyst, Software and services Research, IDC India, the total Indian SCM solutions market is growing at a CAGR of $7.6 \%$ and is expected to touch US\$ $132.6 \mathrm{mn}$ by 2011. "The India Supply Chain Management solutions market in 2009 was US\$ $91.8 \mathrm{mn}$ with the major players being SAP, Oracle and Invensys, Lawson and Information. The year -on - year growth for the India Supply Chain Management market took a hit during the global slowdown but is expected to recover in 2010 and beyond. But if, we talk of present position of Supply Chain in India then, its growing at slow pace .Despite a high growth industry such as retailing, the country does not have the Supply chain Infrastructure to take advantage of the tremendous growth in the India because of following reasons:

A. A report by the CII, Confederation of Indian industry and Amarthi Consulting, \$ 65 bn is lost each year on account of the inefficient Supply Chain Infrastructure in India. B. Supply chain costs in India are as much as $13 \%$ of GDP as compared to $7 \%$ in developed countries.

C. Since 1947 , the railway network has increased only $20 \%$ in size, while the traffic it accommodates has increased tenfold.

D. The lack of an integrated cold chain infrastructure means that farm produce worth $\$ 13$ bn is wasted every year.

E. Capacity constraints at airports causes' airline fuel consumption to increase by up to $30 \%$.[8]

F. Investment in Road Infrastructure has not kept pace with the growth in road traffic. Only $20 \%$ of the roads are in good condition.

Retail giant Wal-Mart says that at least $40 \%$ of produce in India is wasted because of inadequate storage \& transportation.[9]

\section{COMPARISON of INDIA'S SUPPLY CHAIN}

\section{WITH CHINA}

Table: 1 Comparison of India's Supply Chain with China [12]

\begin{tabular}{|l|l|}
\hline India & China \\
\hline $\begin{array}{l}\text { 1. Higher productivity levels } \\
\text { in India, in terms of capital } \\
\text { intensity, delivery, frequency } \\
\text { \& stock turn ratio. }\end{array}$ & 1 China is having edge in it. \\
\hline $\begin{array}{l}\text { 2. Within India there is a } \\
\text { heavy reliance of roads. } \\
\text { Their network is the second } \\
\text { largest in the world behind } \\
\text { the U.S., at over } 3 \text { mn } \\
\text { kilometers }\end{array}$ & $\begin{array}{l}\text { 2. China, in contrast, has a } \\
\text { roads. Out of its million plus } \\
\text { kilometer road network, only } \\
\text { around 300,000 kilometers } \\
\text { are paved }\end{array}$ \\
\hline $\begin{array}{l}\text { 3. Less number of multiple } \\
\text { lane highways. }\end{array}$ & $\begin{array}{l}\text { 3. It has five times the } \\
\text { number of multiple lane }\end{array}$ \\
\hline
\end{tabular}

\begin{tabular}{|c|c|}
\hline & highways than India \\
\hline 4. Less transport options. & $\begin{array}{l}\text { 4. China also has more } \\
\text { transport options available to } \\
\text { its supply chains in the form } \\
\text { of rail, air \& waterways. }\end{array}$ \\
\hline $\begin{array}{l}5.63,000 \mathrm{kms} \text { of terrain are } \\
\text { connected by rail in India }\end{array}$ & $\begin{array}{l}5 . \text { Over } 78,000 \mathrm{kms} \text { of terrain } \\
\text { are connected by rail in } \\
\text { china }\end{array}$ \\
\hline $\begin{array}{l}\text { 6.There are only } 334 \\
\text { locations to take to the sky in } \\
\text { India }\end{array}$ & $\begin{array}{l}\text { 6. Goods can be flown in } \& \\
\text { out of China by way of } 500 \\
\text { airports }\end{array}$ \\
\hline $\begin{array}{l}\text { 7. India is having } 16,000 \mathrm{kms} \\
\text { of waterways particularly in } \\
\text { the movement of bulk } \\
\text { commodities. }\end{array}$ & $\begin{array}{l}\text { 7. China has more navigable } \\
\text { waterways. Commerce in } \\
\text { China moves on } 1,10,000 \\
\text { kms of inland aqueous } \\
\text { passageways. }\end{array}$ \\
\hline $\begin{array}{l}\text { 8. India is having edge than } \\
\text { China in youngest } \\
\text { population. India will add } 71 \\
\text { million to its working age } \\
\text { population of } 691 \text { million by } \\
2010 \text {, according to estimates } \\
\text { by United Nations. }\end{array}$ & $\begin{array}{l}\text { 8. Rate of young population } \\
\text { in China is declining since } \\
2000 . \text { only } 22.8 \% \text { of people } \\
\text { falls in the age group of } 15 \text { - } \\
29 .[10],[11]\end{array}$ \\
\hline $\begin{array}{l}\text { 9. India is at 2nd number out } \\
\text { of all BRIIC countries( } 47 \text { th } \\
\text { rank) }\end{array}$ & $\begin{array}{l}\text { 9. According to World } \\
\text { Bank's logistics performance } \\
\text { Banking: China is ranked the } \\
\text { highest of all BRIIC } \\
\text { countries (27th rank) in } \\
\text { terms of customs clearance, } \\
\text { infrastructure, adequacy, } \\
\text { logistics, timeliness and } \\
\text { tracking ability place. }\end{array}$ \\
\hline $\begin{array}{l}\text { 10. Size of local market is } \\
\text { less in comparison to China. }\end{array}$ & $\begin{array}{l}\text { 10. China's local market is } \\
\text { big in comparison to India . } \\
\text { Its GDP is almost three times } \\
\text { that of India and it has more } \\
\text { consumers with buying } \\
\text { power }\end{array}$ \\
\hline
\end{tabular}

\section{PERFORMANCE OF INDIA AMONG BRIIC} COUNTRIES

\begin{tabular}{|l|l|l|l|l|l|l|}
\hline Country & Rank & LPI & Infr & $\begin{array}{l}\text { Int } \\
\text { Sh }\end{array}$ & Lgstc & Time \\
\hline China & 27 & 3.49 & 3.54 & 3.31 & 3.49 & 3.91 \\
\hline India & 47 & 3.12 & 2.91 & 3.13 & 3.16 & 3.61 \\
\hline Brazil & 41 & 3.20 & 3.10 & 2.91 & 3.30 & 4.14 \\
\hline Ind onesia & 75 & 2.76 & 2.54 & 2.82 & 2.47 & 3.46 \\
\hline Russia & 94 & 2.61 & 2.38 & 2.72 & 2.51 & 3.23 \\
\hline
\end{tabular}

Fig.1 Example of Performance of India among BRIIC countries [13],[14]

Where, Rank- World Rank

LPI- Cumulative Logistics Performance Index

Infr- Infrastructure

Int SH- International Shipping

Lgstc- Logistics

Time- Timeliness 


\section{ANALYSIS}

Both India and China rank among the front runners of global economy and are among the World's most diverse nations.[15]But if we make the analysis of the India v/s China, we can see that there are no. of factors that has made China better than India. In terms of Supply Chain and Infrastructure, China is having the edge. The basic reason behind the success story of China is because of its developed economy.

India has become much more developed than before It is having a number of opportunities available with it. .[16] Only thing is that, even then it is not able to make right business out of it. So Indian govt. is required to make some investments and to keep a vigil check on the operations of the supply chain \& infrastructure Then only its present condition can be improved.

\section{CONCLUSIONS}

Gone are the days where customer service was merely a buzz word. With the focus on customer service, companies have moved away for a supply driven business towards a demand driven business. Companies are also constantly searching for ways to reduce inventory and holding cost. The increase in speed has forced companies to search for ways to reduce product cycle time and move product quickly and cost effectively. With this the concept of Supply chain has emerged to be one of the important sectors across worldwide. It is so considered because of the time utility factor concerned with it. Supply Chain Management with I.T. services has completely changed the outlook of how companies manage their supply Chain and how they maintain their collaborative relationships with their suppliers and satisfy the needs of their customers. This paper depicts the emerging trends in Supply Chain as well as points out the difference of India's Supply Chain with that of India, in which China proves to have competitive edge. India is one of the world's fastest growing economies with diverse markets. Managing Supply Chain in such a vast country is most challenging for any organization because of business practices, govt. regulation, technology, capability, transportation and infrastructure. Thus in every case, Indian Organization need to act fast to capitalize on these opportunists to be competitive with the world market.[17]

\section{REFERENCES}

[1] (2010),Wikipedia/Supply Chain Management website.[online].Available:

http://en.wikipedia.org/wiki/Supply_chain_manageme nt

[2] Delft University of technology,(2001-2009),Global Supply Chain website.[online]. Available: http://sk3.tbm.tudelft.nl:8080/opencms/opencms/gscg/backgro und_info/

[3] A.Tambi(2009) Supply Chain website[online]. Available: http://it.toolbox.com/blogs/everythinganything-supply-chains/who- has-a-higher-logistics- cost-china-or-india-35123

[4] (2010),Wikipedia/Vendor-managed

inventory

website.[online].Available:

http://en.wikipedia.org/wiki/Vendor-

managed_inventory

[5] (2000),Collaborative Planning, Forecasting \& Replishment website.[online].Available: http://www28.sap.com/businessmaps/91039F49E53F1 1D3874B000 0E820132C.htm

[6] M.Jajima," Stategic Value of RFID in Supply Chain Management “, Journal of Purchasing \& Supply Chain Management 13(2007) 261273, Ontario, Canada.

[7] (2010),ERP website.[online]. Available: http://whatiserp.net/other- softwarebusiness/emerging-technologies-in-supply-chainmanagement/

[8] M. Martin (2010) Logistics/Supply Chain website[online].

Available:http://logistics.about.com/b/2010/09/02/sup ply-chain-issues-cost-india-65-billion-each-year.htm

[9] (2010) Money control/Business News website[online]. Available:

http://www.moneycontrol.com/news/business/walmart-india-growth-faces-supply-chainhurdle_473232.html

[10] (2008),sinaenglish/china website.[online].Available: http://english.sina.com/china/1/2007/1224/138380.htm 1

[11] (2010),Wikipedia website.[online].Available: http://en.wikipedia.org/wiki/Demographics_of_the_Pe ople's_Repub lic_of_China

[12] Charles,(2010).China and India website.[online]. Available:

http://www.chinasourcingblog.org/2010/01/china-andindia-a- comparison-i.html

[13] (2010) World Bank/Logistics Performance Index website[online].

Available: http://info.worldbank.org/etools/tradesurvey/mode1b.a sp

[14] E.Duncan,(2010),Company reports/Industry Focus/Outsourcing website.[Online].Available: http://www.supplychaindigital.com/industryfocus/outsource/outsourcing-hubs-china-india-easterneurope

[15] FigDaksha.(2010).Logisticswebsite.[online].Available : http://www.logistics-scm.com/2010/05/06/india-vschina-economy-2009/

[16] B.S.Sahay, J.N.D Gupta, R.Mohan," Managing Supply Chain for Competitiveness: The Indian Scenario", Supply Chain Management: An International Journal Volume 11,(2006),pp-15- 24,India 